\title{
Development of Instant Dosa Batter Mix with Enhanced Nutritive Value and its Storage Study
}

\author{
Selvaraj Rama Jeba ${ }^{1}$, Kandasamy Karthikeyan ${ }^{1}$ and Dorathy Pushparani $\mathbf{i}^{*}$ \\ 1Department of Food Science and Nutrition, Periyar University, Salem - 636011, Tamil Nadu, India. \\ ²Department of Food Chemistry and Food Processing, Loyola College, Chennai - 600034, \\ Tamil Nadu, India; dorothychris25@gmail.com
}

\begin{abstract}
The present study was undertaken to formulate an instant dosa batter with enhanced nutritive value. The traditional ingredients were replaced using brown rice, white rice, black gram, oats, finger millet, sorghum, foxtail millet to develop a novel breakfast dosa batter with enhanced taste and nutritional benefits. Control dosa batter was prepared using white rice and black gram in 4:1 ratio. The developed batter was made into dosa and the products were compared for nutritional composition, sensory parameters and storage study. The developed dosa was highly acceptable on organoleptic evaluation with an overall acceptability score of 4.1. The addition of oats enhanced the taste. Notable change in nutritive value was observed between control and trial dosa. Macro nutrients in gm such as protein $(11.55 \mathrm{~g})$, fat $(0.88 \mathrm{~g})$, fibre $(2.33 \mathrm{~g})$, and ash $(1.64 \mathrm{~g})$ is increased $(\mathrm{gm} / 100 \mathrm{gm})$. Compared to the control dosa the micronutrients content $(\mathrm{mg} / 100 \mathrm{gm})$ like iron $(33.3 \mathrm{mg})$, phosphorous $(48.9 \mathrm{mg})$, potassium $(99.3 \mathrm{mg})$, calcium $(88.1 \mathrm{mg})$ was also higher in the trial. Storage study was done for five days in refrigeration condition and the microbiological test was done. The acidity was calculated each day for both control and trial batter On $0^{\text {th }}$ day the acidity for control was 1.20 and for trial it was 2.0 and on $4^{\text {th }}$ day for control it was 4.89 and for trial it was 4.90 due to over fermentation of the batter.
\end{abstract}

Keywords: Brown Rice, Millets, Nutritive Value, Storage Study, White Rice

\section{Introduction}

Dosa is a traditional food of South India. It is easily digestible and contributes to the diet as a source of protein, calories and vitamins, especially B-complex vitamins, compared to the raw unfermented ingredients ${ }^{1}$.

According to Babu (2009) "The complete milling and polishing that converts brown rice into white rice destroys $67 \%$ of the vitamin $B_{3}, 80 \%$ of the vitamin $B_{1}$, $90 \%$ of the vitamin $B_{6}$ half of the manganese, half of the phosphorus, $60 \%$ of the iron and all of the dietary fiber and essential fatty acids". "Replacing as little as a third of a daily serving of white rice with an equal amount of brown rice may lower the risk of type 2 diabetes, and replacing white rice with other types of whole grains can cut the risk even more" ${ }^{\text {. }}$
"Minor cereals consisting of maize, sorghum, pearl millet, finger millet and other millets constitute a little less than 25\% (33.92 million tons) of the total food grain production (209.2 million tons) in India"4.

The bran and germ fractions derived from conventional milling provide a majority of the biologically active compounds. Specific nutrients include high concentrations of B vitamins and minerals, elevated levels of basic amino acids (for example, arginine and lysine), and elevated tocol levels in the lipids ${ }^{6}$.

Brown rice is healthier due to the anti-oxidant that is beneficial in helping to reduce Coronary Heart Diseases (CHD). Taking brown rice, which contains insoluble fibre, help women to prevent gallstones ${ }^{8}$. The nutritive value given by NIN and UDSA is supportive of this

${ }^{*}$ Author for correspondence 
Table 1. Effect of milling on nutritive content of rice ${ }^{5}$

\begin{tabular}{|c|c|c|}
\hline \multirow{2}{*}{ Nutrients } & \multicolumn{2}{|c|}{ Extraction rate (\%) } \\
\cline { 2 - 3 } & White rice & Brown rice \\
\hline Calcium $(\mathrm{mg} / \mathrm{g})$ & 0.1 & 0.1 \\
\hline Phosphorous $(\mathrm{mg} / \mathrm{g})$ & 1.5 & 3.2 \\
\hline Niacin $(\mathrm{mg})$ & 6.0 & 29.0 \\
\hline Iron $(\mathrm{mg})$ & 4.1 & 8.8 \\
\hline Biotin $(\mathrm{mg})$ & 43.0 & 48.0 \\
\hline
\end{tabular}

Table 2. Nutrient content of rice

\begin{tabular}{|c|c|c|}
\hline Nutrients (mg/100g) & Brown rice & Polished rice \\
\hline Thiamine & 0.34 & 0.07 \\
\hline Riboflavin & 0.05 & 0.03 \\
\hline Niacin & 4.7 & 1.6 \\
\hline Iron & 1.9 & 0.5 \\
\hline Magnesium & 187.0 & 13.0 \\
\hline
\end{tabular}

increase in value of fibre and ash in trial, due to the choice and proportion of ingredients in the trial dosa. Abdas et al $(2011)^{5}$ have reported that the loss of nutrients resulting from milling in polished rice is very considerable. The degree of milling and polishing determines the amount of nutrients removed ${ }^{9}$.

\section{Materials and Methods}

\subsection{Raw Materials}

White rice, urad dhal, oats, ragi flour and other minor ingredients were procured from super market in Chennai for preparation of control a batter, Brown rice, foxtail flour, jowar flour was procured from Wayannadu, Kerala for the preparation of the dosa batter.

\subsection{Preparation of Control Dosa Batter}

Preparation of dosa batter by traditional method using rice and urad dhal and for the variation brown rice and millets were used as per the procedure followed by Babu et al. (2009)2 .

\subsection{Nutrient Analysis}

All the parameters like macronutrients (carbohydrate, fat, fibre, protein) and micronutrient (minerals) were determined by the proceeding followed by AOAC (2005) ${ }^{10}$ and FSSAI (2009) ${ }^{11}$.

\subsection{Sensory Evaluation}

The organoleptic characteristics of product and standard were evaluated by 30 panel member. The panel were asked to evaluate the products for colour, appearance, taste, flavour, texture, and overall acceptability for which 5 -point hedonic scale was used.

\subsection{Storage Study of Dosa Batter}

The product was stored for 30 days and the enumeration of microbial count in the sample stored in different packaging material was done by standard plate count method (TPC) and for the presence of E-Coli.

\section{Result and Discussion}

The protein content in whole grains of minor millets varied from $4.76 \%$ in Finger millet to $13.10 \%$ in Foxtail millet. Foxtail and barnyard millet showed comparable amounts of crude protein which was highest among all the millets studied and were followed by little millet, Kodo millet and Finger millet it was observed that minor millets vary from one another in their protein contents ${ }^{12}$. The boosting of protein, calcium and iron in the dosa batter would enhance the millet flour. The nutritional composition of millets in the dry form is given in (Table 3 and 4).

The novel convenient ready to make instant dosa batter with enhanced nutritive value using whole grains and millets (TRIAL) brown rice, white rice, black gram

Table 3. Nutritional composition of sorgam, foxtail and Finger millet (g/100g, -dry basis)

\begin{tabular}{|c|c|c|c|}
\hline Component & $\begin{array}{c}\text { Sorghum } \\
\text { (Jowar) } \\
\text { Flour }\end{array}$ & $\begin{array}{c}\text { Foxtail } \\
\text { Millet } \\
\text { (THENAI) } \\
\text { Flour }\end{array}$ & $\begin{array}{c}\text { Finger } \\
\text { Millet } \\
\text { (ragi) } \\
\text { Flour }\end{array}$ \\
\hline Protein & 11.58 & 11.50 & 8.2 \\
\hline Ash & - & 0.47 & 2.7 \\
\hline Fat & 4.9 & 2.38 & 1.8 \\
\hline Cho & 80.1 & 75.2 & 83.3 \\
\hline Fibre & 0.7 & - & 3.5 \\
\hline
\end{tabular}

Table 4. Micronutrient analysis of Millets

\begin{tabular}{|c|c|c|c|}
\hline $\begin{array}{c}\text { Materials } \\
(\mathbf{1 0 0 g})\end{array}$ & $\begin{array}{c}\text { Calcium } \\
(\mathbf{m g})\end{array}$ & $\begin{array}{c}\text { Phosphorous } \\
(\mathbf{m g})\end{array}$ & $\begin{array}{c}\text { Iron } \\
(\mathbf{m g})\end{array}$ \\
\hline $\begin{array}{c}\text { Jowar } \\
\text { (cholam) }\end{array}$ & 25 & 222 & 4.1 \\
\hline $\begin{array}{c}\text { Finger } \\
\text { (ragi) }\end{array}$ & 344 & 283 & 3.9 \\
\hline $\begin{array}{c}\text { Foxtail } \\
\text { (thenai) }\end{array}$ & 27 & 188 & 0.5 \\
\hline
\end{tabular}


dhal, finger millet, sorghum and foxtail millet was developed and results of the nutritive analysis of this in comparision to traditional dosa batter mix (CONTROL) made with white rice and black gram dhal (4:1) is given in the Table 5.

Each $100 \mathrm{gms}$ of control dosa contain $14.39 \mathrm{gm}$ carbohydrate, $1.54 \mathrm{gm}$ fat, $10.78 \mathrm{gm}$ protein, $1.56 \mathrm{gm}$ fibre each $100 \mathrm{gm}$ of trial dosa contain $15.29 \mathrm{gm}$ carbohydrate, $0.88 \mathrm{gm}$ fat, $11.55 \mathrm{gm}$ protein, $2.33 \mathrm{gm}$ fibre.

The carbohydrate value in trial (15.29 gm) was slightly higher that control (14.39 gm) (Figure 1). The carbohydrate content does not vary much between white rice and brown rice. The fibre in the trial $(2.33 \mathrm{gm})$ was higher compared to control (1.56 gm). The main contribution towards increase in fibre could be attributed to the higher in gms of fibre in brown rice compare to white rice. Studies given below also conclude that brown rice is a rich source of fibre. Brown rice is a whole grain meaning it contains a large amount of fibre ${ }^{8}$. The minerals content in trial dosa is higher then in control. Nutritive values given by NIN have reported that all the ingredients used in trial dosa have higher micronutrient content compared to control in the trial. The following studies also support the higher content of nutrients in the trial ingredients.

The phosphorous content in the trial was $48.9 \mathrm{mg}$ higher and that of control was $45.6 \mathrm{mg}$ (Figure 2). The

Table 5. Nutritive Value of Macronutrients in Dosa $(\mathrm{g} / 100 \mathrm{~g})$

\begin{tabular}{|c|c|c|}
\hline Parameters & Control & Trial \\
\hline Moisture & 56.16 & 60.51 \\
\hline Carbohydrate & 14.39 & 15.29 \\
\hline Fat & 1.54 & 0.88 \\
\hline Protein & 10.78 & 11.55 \\
\hline Ash & 1.18 & 1.64 \\
\hline Fibre & 1.56 & 2.33 \\
\hline
\end{tabular}

Table 6. Shelf Life of Control and Trial Batter

\begin{tabular}{|c|c|c|c|c|c|}
\hline \multirow{2}{*}{ S.No } & \multirow{2}{*}{$\begin{array}{l}\text { Period } \\
\text { (days) }\end{array}$} & \multicolumn{2}{|c|}{ Control Batter } & \multicolumn{2}{|c|}{ Trial Batter } \\
\hline & & $\begin{array}{c}\text { Total Plate } \\
\text { Count } \\
(\mathrm{Cfu} / \mathrm{ml})\end{array}$ & E.Coli & $\begin{array}{c}\text { Total Plate } \\
\text { Count } \\
(\mathrm{Cfu} / \mathrm{ml})\end{array}$ & E.Coli \\
\hline 1. & $\mathbf{0}$ & $0.9 \times 10^{6}$ & 0 & $1.2 \times 10^{6}$ & 1 \\
\hline 2. & 2 & $1.2 \times 10^{6}$ & 3 & $1.9 \times 10^{6}$ & 2 \\
\hline 3. & 3 & $1.9 \times 10^{6}$ & 4 & $2.3 \times 10^{6}$ & 5 \\
\hline
\end{tabular}

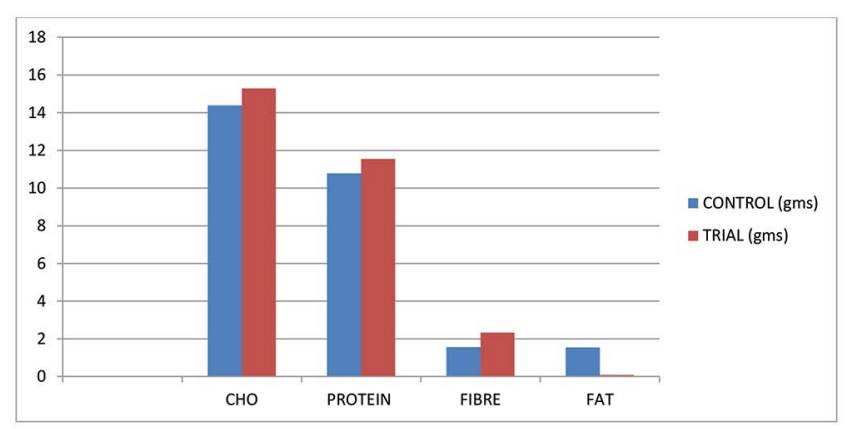

Figure 1. Comparison of macronutrients between control and trial dosa.

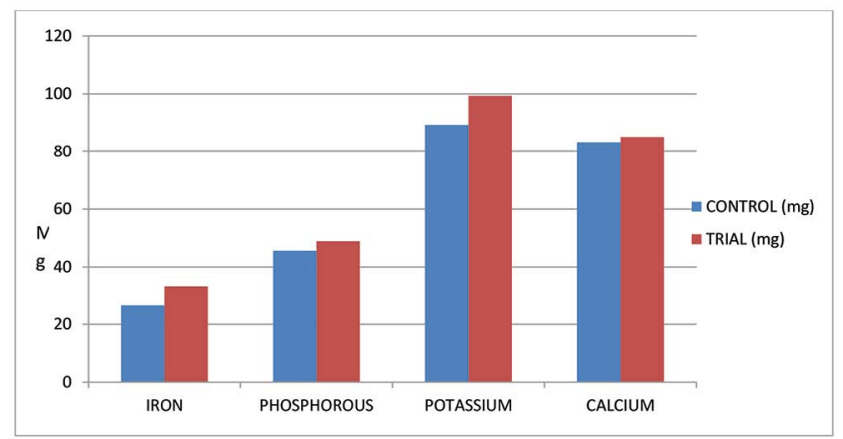

Figure 2. Comparison of micronutrients between control and trial dosa.

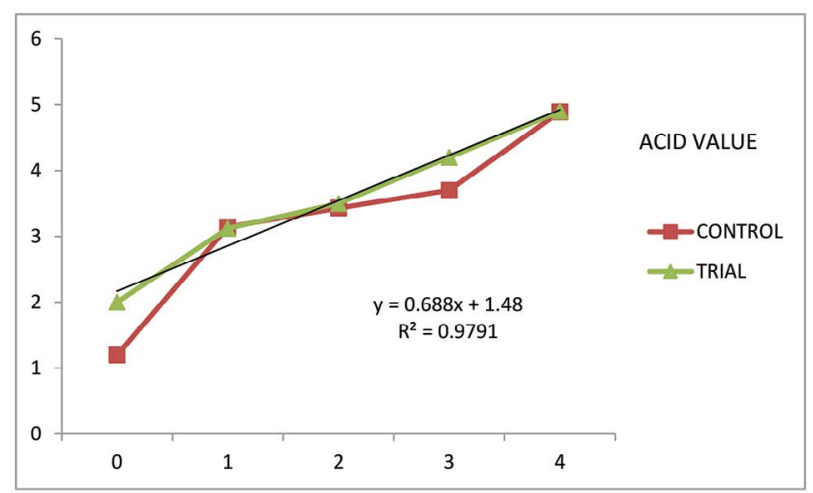

Figure 3. Acidity of the Batter.

potassium content in the trial was $(99.3 \mathrm{mg})$ was higher than the control was $(89.3 \mathrm{mg})$. Although black gram dhal is also rich in micronutrients the oats and millets added to trial dosa were able to impart the same value or higher value of micro nutrient content as the control dosa.

\subsection{Storage Study}

Finally a storage study was undertaken for the instant dosa batter. The batter was found to be fresh and edible for more than five days in refrigerator condition. The batter in placed in two different packaging materials like 
metallised and polythene pouches and the microbial test were performed for $0^{\text {th }}$ day, $2^{\text {nd }}$ day, and $3^{\text {rd }}$ day for both trial batter and control batter. The acidity was calculated each day for both control and trial batter (Figure 3 ) on $0^{\text {th }}$ day for control (1.20) and for trial (2.0) and on $4^{\text {th }}$ day for control (4.89) and for trial (4.90) indicates acid formation due to over fermentation of the batter.

\subsection{Sensory Evalution}

The final products of control and trial dosa were subjected to sensory evaluation and nutritional analysis. The overall acceptability score for trial dosa was 4.1 and for control was 3.7 (Figure 4). The formulated dosa was found to be superior on organoleptic evaluation. The taste of the product was enhanced by addition of oats and minor millets.

\section{Conclusion}

The developed dosa was analysed for its nutritive content in comparision to the control dosa (white rice and black gram 4:1). Increase in macronutrients and micronutrients were observed in the trial dosa compared to the control dosa. This increase in trial can be attributed to the nutritive contribution from brown rice which is rich in proteins, fats, fibre and minerals.

Millets are rich in iron, calcium, phosphorus and potassium. The nutritional composition of the trial dosa was higher as compared with control dosa due to the minor millets used in the trial dosa which are high in minerals. Oats while enhancing the taste is also rich in fibre and minerals and thus contributes to the nutritional composition of the trial dosa. The nutritive value of trial dosa was higher compared to control dosa. As discussed earlier the ingredients used in the trial dosa with higher

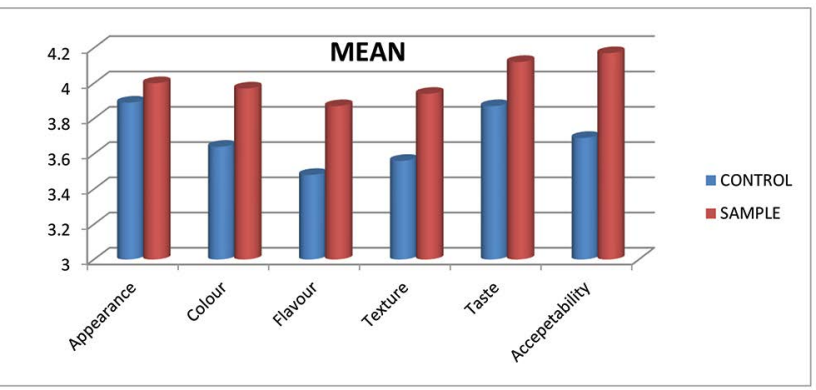

Figure 4. Comparison of Mean Acceptability Value between Control and Trial. nutritive value resulted in increased nutritional content. It was also seen that the nutritional composition of batter when converted into final product as dosa was not much affected by heat.

\section{Reference}

1. Nagaraju VD and Manohar B. Rheology and particle size changes during Idli fermentation. Journal of Food Engineering. 2000; 43(3): 167-71. https://doi.org/10.1016/S0260-8774(99)00146-6

2. Babu DP, Subhasree RS, Bhakyaraj R and Vidhyalakshmi R. Brown rice-beyond the color reviving a lost health food A Review. American-Eurasian Journal of Agronomy. 2009; 2(2): 67-72.

3. Panlasigui LN and Thompson LU. Blood glucose lowering effects of brown rice in normal and diabetic subjects. Journal of Food Science and Nutrition. 2006; 57(3-4): 151-8. https://doi.org/10.1080/09637480500410879

4. Chakhiyar AR. Production, consumption and Marketing pattern of minor millets in Surguja district of Chhattisgarh (Doctoral dissertation, Indira Gandhi Krishi Vishwavidyalaya, Raipur). 2007.

5. Abbas A, Murtaza S, Aslam F, Khawar A, Rafique S and Naheed S. Effect of processing on nutritional value of rice (Oryzasativa). World Journal of Medical Sciences. 2011; 6(2): 68-73.

6. Miller G, Prakash A, Decker E. Whole grain micronutrients in L Marquart, JL Slavin and RG Fulher (Eds), Whole grain foods in health and Disease, Eagan Press ST Paul., MN. 2002; p. 243-58.

7. $\mathrm{Oh} \mathrm{CH}$ and $\mathrm{Oh} \mathrm{SH}$. Effects of germinated brown rice extracts with enhanced levels of GABA on cancer cell proliferation and apoptosis. JournalofMedicinalFood.2004; 7(1): 19-23. https://doi.org/10.1089/109662004322984653 PMid:15117548

8. Chao JL, Tsai YC, Chiu SJ and Sun YH. Localized Notch signal acts through eyg and upd to promote global growth in Drosophila eye. Development. 2004; 131(16): 3839-47. https://doi.org/10.1242/dev.01258 PMid:15253935

9. Wood RT. The Whole Foods Encyclopedia: A Shopper's Guide. Prentice Hall Press. 1988.

10. AOAC International. Determination of moisture, ash, protein and fat. Official method of analysis of the association of analytical chemists (18th ed.). Washington DC: AOAC. 2005.

11. FSSAI; manual of methods of analysis of foods cereal and cereal products. 2009.

12. Chandel G, Meena RK, Dubey M, Kumar M. Nutritional properties of minor millets: neglected cereals with potentials to combat malnutrition. Current Science. 2014; 107(7):1109. 